\title{
Literature references
}

Aalto University (2017). Principles for Commercialisation of Intellectual Property (www.aalto.fi/sites/g/files/flghsv161/files/2018-08/aalto_kaupallistamisen_periaatt eet_eng.pdf).

Adams Becker, S., Cummins, M., Davis, A., Freeman, A., Hall Giesinger, C., and Ananthanarayanan, V. (2017). NMC Horizon Report: 2017 Higher Education Edition. Austin, Texas: The New Media Consortium.

Addie, J-P., Mariarosalba Angrisani, M., and De Falco, S. (2018). University-led innovation in and for peripheral urban areas: new approaches in Naples, Italy and Newark, NJ, US. European Planning Studies, 26(6), 1181-1201.

Audretsch, D. (2014). From the entrepreneurial university to the university for the entrepreneurial society. Journal of Technology Transfer, 39, 313-321.

Benneworth, P. (2012). The relationship of regional engagement to universities' core purposes: reflections from engagement efforts with socially excluded communities. In: Pinheiro, R., Benneworth, P., and Jones, G. (Eds). Universities and Regional Development. A Critical Assessment of Tensions and Contradictions. New York: Routledge, 199-218.

Benneworth, P., and Osborne, M. (2014). Knowledge engagement and higher education in Europe. In: Higher Education in the World: Knowledge, Engagement \& Higher Education: Contributing to Social Change. GUNi series on the social commitment of universities No. 5. Global University Network for Innovation, 219-231.

Benneworth, P., de Boer, H., and Jongbloed, B. (2015). Between good intentions and urgent stakeholder pressures: institutionalizing the universities' third mission in the Swedish context. European Journal of Higher Education, 5, 280-296.

Benneworth, P., Zeeman, N., Pinheiro, R., and Karlsen, J. (2017a). National higher education policies challenging universities' regional engagement activities. Ekonomiaz, 92, 112-139.

Benneworth, P., Young, M., and Normann, R. (2017b). Between rigour and regional relevance? Conceptualising tensions in university engagement for socio-economic development. Higher Education Policy, 30, 443-462.

Benneworth, P., Culum, B., Farnell, T., Kaiser, F., Seeber, M., Šćukanec, N., Vossensteyn, H., and Westerheijden, D. (2018). Mapping and Critical Synthesis of Current State-of-the-Art on Community Engagement in Higher Education. Zagreb: Institute for the Development of Education.

Benneworth, P., and Zeeman, N. (2018). Civic and regional engagement and accountability. In: Hazelkorn, E., Coates, H., and McCormick, A. (Eds). Research Handbook on Quality, Performance and Accountability in Higher Education. Cheltenham, UK and Northampton, MA, USA: Edward Elgar Publishing, 548-559.

Birch, K., and Cumbers, A. (2010). Knowledge, space, and economic governance: the implications of knowledge-based commodity chains for less-favoured regions. Environment and Planning A, 42, 2581-2601. 
Boh, W., De Haan, U., and Strom, R. (2016). University technology transfer through entrepreneurship: faculty and students in spinoffs. Journal of Technology Transfer, 41, 661-669.

Bok, D. (1982). Beyond the Ivory Tower: Social Responsibilities of the Modern University. Cambridge, MA: Harvard University Press.

Bonaccorsi, A. (2016). Addressing the disenchantment: universities and regional development in peripheral regions. Journal of Economic Policy Reform, 20, 293-320.

Borrás, S., and Edquist, C. (2015). Education, training and skills in innovation policy. Science and Public Policy, 42, 215-227.

Boschma, R. (2005). Proximity and innovation: a critical assessment. Regional Studies, $39,61-74$.

Bovill, C., Cook-Sather, A., and Felten, P. (2011). Students as co-creators of teaching approaches, course design, and curricula: implications for academic developers. International Journal for Academic Development, 16, 133-145 (https://doi.org/10 .1080/1360144X.2011.568690).

Breschi, S. (2011). The geography of knowledge flows. In: Cooke, P., Asheim, B., Boschma, R., Martin, R., Schwartz, D., and Toedtling, F. (Eds). Handbook of Regional Innovation and Growth. Cheltenham, UK and Northampton, MA, USA: Edward Elgar Publishing, 132-142.

Brink, C. (2018). The Soul of a University: Why Excellence is Not Enough. Bristol, UK: Bristol University Press.

Brown, R. (2016). Mission impossible? Entrepreneurial universities and peripheral regional innovation systems. Industry and Innovation, 23, 1-17.

Campillo, I., Arregui-Pabollet, E., and Gomez-Prieto, J. (2017). Higher education for smart specialisation: the case of Navarra. JRC Technical Report, European Commission.

Caniëls M., and Van den Bosch, H. (2011). The role of Higher Education Institutions in building regional innovation systems. Papers in Regional Science, 90, 271-286.

Carayannis, E., and Campbell, D. (2009). 'Mode 3' and 'quadruple helix': toward a 21 st century fractal innovation ecosystem. International Journal of Technology Management, 46, 201-234.

Carayannis, E., and Campbell, D. (2012). Mode 3 Knowledge Production in Quadruple Helix Innovation Systems: Twenty-First-Century Democracy, Innovation, and Entrepreneurship for Development. New York, Berlin: Springer Press.

Centre for Educational Research and Innovation (1982). The University and the Community: The Problems of Changing Relationships. Paris: OECD-CERI.

Cervantes, M. (2017). Higher education institutions in the knowledge triangle. Foresight and STI Governance, 11, 27-42.

CESAER (2018). The role of S\&T universities in innovation ecosystems: towards mission 3.1. The Conference of European Schools for Advanced Engineering Education and Research. CESAER White Paper, October 2018, Leuven (Belgium).

Charles, D., Kitagawa, F., and Uyarra, E. (2014). Universities in crisis? New challenges and strategies in two English city-regions. Cambridge Journal of Regions, Economy and Society, 7, 327-348.

Chatterton, P., and Goddard, J. (2000). The response of higher education institutions to regional needs. European Journal of Education, 35, 475-496.

Churchman, C. (1967). Wicked problems. Management Science, 14, B141-B142.

Clark, B. (1998). Creating Entrepreneurial Universities. Oxford: Pergamon Press.

Cooke, E. (1970). Analyzing university student contribution to the economic base of the community. Annals of Regional Science, 4, 146-153. 
Cooke, P., Gomez Uranga, M., and Extebarria, G. (1997). Regional innovation systems: institutional and organisational dimensions. Research Policy, 26, 475-491.

Cooke, P., (2004). Regional innovation systems: an evolutionary approach. In: Cooke, P., Heidenreich, M., and Braczyk, H. (Eds). Regional Innovation Systems: The Role of Governance in a Globalized World. London: Routledge, 1-18.

Cooke, P., Asheim, B., Boschma, R., Martin, R., Schwartz, D., and Tödtling, F. (2011). Handbook of Regional Innovation and Growth. Cheltenham, UK and Northampton, MA, USA: Edward Elgar Publishing.

Council of the European Union (2020). Annex to the Strategic Innovation Agenda of the European Institute of Innovation and Technology (EIT), Partial general approach, 6426/20.

Derrick, G. (2018). The Evaluators' Eye: Impact Assessment and Academic Peer Review. London: Palgrave Macmillan.

Drucker, J., and Goldstein, H. (2007). Assessing the regional economic development impacts of universities: a review of current approaches. International Regional Science Review, 30, 20-46.

Edwards, J., Marinelli, E., Arregui-Pabollet, E., and Kempton, L. (2017). Higher Education for Smart Specialisation - Towards strategic partnerships for innovation. S3 Policy Brief Series No. 23/2017. European Commission Joint Research Centre (Seville).

Edwards, J., Arregui-Pabollet, E., Biagi, F., and Jonkers, K. (2020). Factors influencing the potential of European Higher Education Institutions to contribute to innovation and regional development. JRC Science for Policy Report.

ETER (2019). The regional structure of European higher education. European Tertiary Education Register, Analytical Report no 4 (www.eter-project.com/uploads/ analytical-reports/ETER_AnalyticalReport_04_final.pdf).

Etzkowitz, H., and Leydesdorff, L. (1995). The triple helix-university-industrygovernment relations: a laboratory for knowledge-based economic development. EASST Review, 14, 14-19.

EUA (2018). The future of innovation ecosystems: recommendations from the European Smart Specialisation Workshop. December 2018 (https://eua.eu/ downloads/publications/the $\% 20$ future $\% 20$ of $\% 20$ innovation $\% 20$ ecosystems.pdf).

European Commission (2004). Evaluating EU activities: a practical guide for the Commission Services. Brussels: DG Budget.

European Commission (2010). Regional policy contributing to smart growth in Europe 2020, $\operatorname{COM}(2010) 553$ final. Luxembourg: Publications Office of the European Union.

European Commission (2017a). Measuring the contribution of higher education to innovation capacity in the EU, Study prepared by Q-PLAN International, Manchester Institute for Innovation Research, Centre for Higher Education Policy Studies, Institute for Innovation and Knowledge Management and La Sapienza, European Commission, DG EAC), Luxembourg: Publications Office of the European Union.

European Commission (2017b). A renewed EU agenda for higher education, COM(2017) 247 final. Luxembourg: Publications Office of the European Union.

European Commission (2018a). Main actions implementing the Erasmus Programme accompanying the proposal for a regulation of the European Parliament and of the Council establishing 'Erasmus': the Union programme for education, training, youth and sport, $\operatorname{SWD}(2018) 276$ final.

European Commission (2018b). Appendixes to the proposal for a decision of the European Parliament and of the Council on establishing the specific programme 
implementing Horizon Europe - the Framework Programme for Research and Innovation, $\operatorname{COM}(2018) 436$ final.

European Commission (2018c). Proposal for a regulation of the European Parliament and of the Council laying down common provisions on the European Regional Development Fund, the European Social Fund Plus, the Cohesion Fund, and the European Maritime and Fisheries Fund and financial rules for those and for the Asylum and Migration Fund, the Internal Security Fund and the Border Management and Visa Instrument, COM/2018/375 final - 2018/0196.

European Commission (2018d). Proposal for a regulation of the European Parliament and of the Council establishing Horizon Europe - the Framework Programme for Research and Innovation, laying down its rules for participation and dissemination, COM 2018/435.

European Commission (2018e). Proposal for a regulation of the European Parliament and of the Council establishing 'Erasmus': the Union programme for education, training, youth and sport; and repealing Regulation (EU) No 1288/2013.

European Commission (2019a). Reflection Paper: Towards a sustainable Europe by 2030, European Commission.

European Commission (2019b). Final reflections of the RISE Group, European Commission, DG R\&I. Luxembourg: Publications Office of the European Union.

European Commission (2019c). Proposal for a Decision of the European Parliament and of Council on the Strategic Innovation Agenda of the European Institute of Innovation and Technology (EIT) 2021-2027, COM(2019) 330 final.

European Commission (2020). A robust innovation ecosystem for the future of Europe: report on the results of the Stakeholder Consultation. European Commission, DG Research and Innovation. Luxembourg: Publications Office of the European Union.

Feldman, M. (2001). The entrepreneurial event revisited: firm formation in a regional context. Industrial and Corporate Change, 10, 61-891.

Fitjar, R., Benneworth, P., and Asheim, B. (2019). Towards regional responsible research and innovation? Integrating RRI and RIS3 in European innovation policy. Science and Public Policy, scz029 (https://doi.org/10.1093/scipol/scz029).

Flanagan, K., Uyarra, E., and Laranja. M. (2011). Reconceptualising the 'policy mix' for innovation. Research Policy, 40, 702-713.

Foray, D., and Goenaga, X. (2013). The Goals of Smart Specialisation. Brussels: European Commission, DG JRC, S3 Policy Brief Series No. 01/2013.

Foray, D. (2014). Smart Specialisation: Opportunities and Challenges for Regional Innovation Policy. Abingdon: Routledge.

Foray, D. (2018). Smart specialisation and industrial modernisation in European regions - theory and practice. Cambridge Journal of Economics, 42, 1505-1520.

Foray, D., Morgan, K., and Radosevic, S. (2018). The role of smart specialization in the EU research and innovation policy landscape. DG Regio Working Paper, European Commission.

Foray, D. (2019). In response to 'Six critical questions about smart specialisation'. European Planning Studies, 27, 2066-2078.

Gianelle, C., Kiriakou, D., Cohen, C., and Przeor, M. (2016). Implementing Smart Strategies: A Handbook. Luxembourg: Publications Office of the European Union.

Gibbons, M., Limoges, C., Nowotny, H., Schwartzman, S., Scott, P., and Trow, M. (1994). The New Production of Knowledge. The Dynamics of Science and Research in Contemporary Societies. London: Sage.

Goddard, J., Kempton, L., and Vallance, P. (2013). Universities and smart specialisation: challenges, tensions and opportunities for the innovation strategies of European 
regions, EKONOMIAZ. Revista vasca de Economía. Gobierno Vasco / Eusko Jaurlaritza / Basque Government, 83, 83-102.

Goddard, J., and Vallance, P. (2013). The University and the City. Abingdon: Routledge.

Goddard J., Hazelkorn, E., Kempton, L., and Vallance P. (2016). The Civic University: The Policy and Leadership Challenges. Cheltenham, UK and Northampton, MA, USA: Edward Elgar Publishing.

Goldstein, H., Maier, G., and Luger, M. (1995). The university as an instrument for economic and business development: U.S. and European comparisons. In: Dill, D., and Sporn, B. (Eds). Emerging Patterns of Social Demand and University Reform: Through a Glass Darkly. Oxford, UK: Pergamon Publishers, 105-133.

Goldstein, H., and Renault, C. (2004). Contributions of universities to regional economic development: a quasi-experimental approach. Regional Studies, 38, 733-746.

Goldstein, H., and Drucker, J. (2006). The economic development impacts of universities on regions: do size and distance matter? Economic Development Quarterly, 20, 22-43.

Goldstein, H. (2010). The 'entrepreneurial turn' and regional economic mission of universities. The Annals of Regional Science, 44, 83-109.

Hazelkorn, E. (2016). Contemporary debates part I: theorising civic engagement. In: Goddard, J., Hazelkorn, E., Kempton, L., and Vallance, P. (Eds). The Civic University: The Policy and Leadership Challenges. Cheltenham, UK and Northampton, MA, USA: Edward Elgar Publishing, 36-64.

Hazelkorn, E. (2018). Reshaping the world order of higher education: the role and impact of rankings on national and global systems. Policy Reviews in Higher Education, 2, 4-31.

Hazelkorn, E., and Edwards, J. (2019). Skills and smart specialisation. The role of vocational education and training in smart specialisation strategies. European Commission. JRC Science for Policy Report.

Hicks, D. (2012). Performance-based university research funding systems. Research Policy, 41, 251-261.

Hill J., Walkington, H., and France, D. (2016). Graduate attributes: implications for higher education practice and policy. Journal of Geography in Higher Education, 40(2), 155-163.

Hristov, H., Slavcheva, M., Jonkers, K., and Szkuta, K. (2016). Intersectoral mobility and knowledge transfer. Preliminary evidence of the impact of intersectoral mobility policy instruments. European Commission Report EUR 28027 EN.

Huggins, R., and Johnston, A. (2009a). The economic and innovation contribution of universities: a regional perspective. Environment and Planning C: Government and Policy, 27, 1088-1106.

Huggins, R., and Johnston, A. (2009b). Knowledge networks in an uncompetitive region: SME innovation and growth. Growth and Change, 40, 227-259.

Huggins, R., and Kitagawa, F. (2012). Regional policy and university knowledge transfer: perspectives from devolved regions in the UK. Regional Studies, 46, 817-832.

Johannessen J-A., and Skaalsvik, H. (2014). Innovative leadership in organizations: the road to innovation performance. Problems and Perspectives in Management, 12, $139-152$.

Jones, C., and English, J. (2004). A contemporary approach to entrepreneurship education. Education and Training, 46(8/9), 416-423 (https://doi.org/10.1108/ 00400910410569533). 
Jongbloed, B., Vossensteyn, H., Van Vught, F., and Westerheijden, D. (2018). Transparency in higher education: the emergence of a new perspective on higher education governance. In: Curaj, A., Deca, L. and Pricopie, R. (Eds). European Higher Education Area: The Impact of Past and Future Policies. New York: Springer, 441-454.

Jonkers K., and Zacharewicz, T. (2017). Research performance based funding systems: a comparative assessment. JRC Science for Policy report EUR 27837. Brussels: European Commission.

Jonkers, K., Tijssen, R., Karvounaraki, A., and Goenaga, X. (2018). A Regional Innovation Impact Assessment Framework for Universities. Luxembourg: Publications Office of the European Union.

Kempton, L., Goddard, J., Edwards, J., Hegyi, F., and Elena-Pérez, S. (2013). Universities and smart specialisation, Seville: European Commission, DG JRC, S3 Policy Briefs Series, no. 3/2013, Report EUR 26343 EN.

Kempton, L. (2016). Institutional challenges and tensions. In: Goddard, J., Hazelkorn, E., Kempton, L., and Vallance, P. (Eds). The Civic University: The Policy and Leadership Challenges. Cheltenham, UK and Northampton, MA, USA: Edward Elgar Publishing, 281-297.

Kempton, L. (2019). Wishful thinking? Towards a more realistic role for universities in regional innovation policy. European Planning Studies, 27, 2248-2265.

Kerr, C. (2001). The Uses of the University, 5th edition. Cambridge, MA: Harvard University Press.

Lackéus, M., and Williams-Middleton, K. (2015). Venture creation programs: bridging entrepreneurship education and technology transfer. Education+Training, 57, $48-73$.

Lamy, P. et al. (2017). LAB - FAB - APP: Investing in the European future we want. Brussels, European Commission: Report of the independent High Level Group on maximising the impact of EU Research \& Innovation Programmes.

Laranja, M., Uyarra E., and Flanagan, K. (2008). Policies for science, technology and innovation: translating rationales into regional policies in a multi-level setting. Research Policy, 37, 823-835.

Laursen, K., Reichstein, T., and Salter, A. (2011). Exploring the effect of geographical proximity and university quality on university-industry collaboration in the United Kingdom. Regional Studies, 45, 507-523.

Laursen, K., Masciarelli, F., and Prencipe, A. (2012). Regions matter: how localised social capital affects innovation and external knowledge acquisition. Organisation Science, 23(1), 177-193.

Lepori, B. (2016). Universities of applied sciences in the Swiss research and innovation system, in Research and Innovation in Switzerland (SERI report). Bern: State Secretariat for Education, Research and Innovation, 197-218.

Leten, B., Landoni, P., and Van Looy, B. (2014). How do firms benefit from the proximity of universities? Research Policy, 43, 1398-1412.

Malerba, F., Caloghirou Y., McKelvey M., and Radosevic, S. (2015). Dynamics of Knowledge-Intensive Entrepreneurship: Business Strategy and Public Policy. London: Routledge.

Markiewicz, A., and Patrick, I. (2016). Developing Monitoring and Evaluation Frameworks. Thousand Oaks, CA: Sage.

Martin, B. (2011). The Research Excellence Framework and the 'impact agenda': are we creating a Frankenstein monster? Research Evaluation, 20, 247-254. 
Mejlgaard, N., and Ryan, T. (2017). Patterns of third mission engagement among scientists and engineers. Research Evaluation, 26, 326-336.

Molas-Gallart, J., and Castro-Martínez, E. (2007). Ambiguity and conflict in the development of 'Third Mission' indicators. Research Evaluation, 16, 321-330.

Morgan, K. (1997). The learning region: institutions, innovation and regional renewal. Regional Studies, 41, S147-S159.

Mustar, P. (2002). Public support for the spin-off companies from higher education and research institutions. In: Proceedings of the STRATA consolidating workshop, Session 4: New instruments for science and technology policy implementation, Brussels: European Commission (Unit RTD-K.2).

Nhamo, G., and Mjimba, V. (Eds) (2020). Sustainable Development Goals and Institutions of Higher Education. New York: Springer International Publishing.

Nilsen, T., and Lauvås, T. (2018). The role of proximity dimensions in facilitating university-industry collaboration in peripheral regions: insights from a comparative case study in northern Norway. Arctic Review on Law and Politics, 9, 312-331.

OECD/EU (2018). Supporting Entrepreneurship and Innovation in Higher Education in the Netherlands. Paris: OECD Skills Studies, OECD Publishing (http://dx.doi.org/ 10.1787/9789264292048-en).

OECD/Eurostat (2018). Oslo Manual 2018: Guidelines for Collecting, Reporting and Using Data on Innovation, 4th edition, The Measurement of Scientific, Technological and Innovation Activities. Paris: OECD Publishing/Luxembourg: Eurostat.

Ollila, S., and Williams-Middleton, K. (2011). The venture creation approach: integrating entrepreneurial education and incubation at the university. International Journal of Entrepreneurship and Innovation Management, 13, 161-178.

Östling, J. (2020). Humboldt's University: the history and topicality of a German tradition. In: Engwall, L. (Ed.). Missions of Universities: Past, Present, Future. New York: Springer, 63-80.

Oughton, C., Landabaso, M., and Morgan, K. (2002). The regional innovation paradox: innovation policy and industrial policy. Journal of Technology Transfer, 27, 97-110.

Ozbolat, N., Haegeman, K., and Sereti, K. (2019). EIT KICs: collaboration in a RIS3 context (https://s3platform.jrc.ec.europa.eu/-/eit-knowledge-and-innovation -communities-collaboration-in-a-ris3-context).

Pfister, C., Rinawi, M., Harhoff, D., and Backes Gellner, U. (2017). Regional effects of applied research, universities of applied sciences and innovation, Working Paper no. 117, Swiss Leading House Economics of Education.

Pinheiro, R., Benneworth, P., and Jones, G. (2015). Beyond the obvious: tensions and volitions surrounding the contributions of universities to regional development and innovation. In: Carmo Farinha, L., Ferreira, J., Lawton Smith, H., and Bagchi-Sen, S. (Eds). Handbook of Research on Global Competitive Advantage through Innovation and Entrepreneurship. Hershey, PA: IGI Global, 150-172.

Pinto, H., Nogueira, C., and Edwards, J. (2021). Higher education and smart specialisation: the case of Portugal. JRC Technical Report. Seville: Joint Research Centre.

Power, D., and Malmberg, A. (2008). The contribution of universities to innovation and economic development: in what sense a regional problem? Cambridge Journal of Regions, Economy and Society, 1, 233-245.

Radosevic, S. (2017). EU smart specialization in a comparative perspective. In: Radosevic, S., Curaj, A., Gheorghiu, R., Andreescu, L., and Wade, I.(Eds). Advances in the Theory and Practice of Smart Specialization. London: Elsevier Science Publishers, 1-36. 
Reichert, S. (2019). The Role of Universities in Regional Innovation Ecosystems. Brussels: European University Association (EUA).

Reillon, V. (2016). The European Institute of Innovation and Technology, Briefing September 2016, European Parliamentary Research Service, Brussels.

Rissola, G., Hervas, S., Slavcheva, M., and Jonkers, K. (2017). Place-based innovation ecosystems. European Commission, JRC Science for Policy Report.

Rosenberg, N., and Nelson, R. (1994). American universities and technical advance in industry. Research Policy, 23, 323-348.

Sánchez-Barrioluengo, M., and Benneworth P. (2019). Is the entrepreneurial university also regionally engaged? Analysing the influence of university's structural configuration on third mission performance. Technological Forecasting and Social Change, 141, 206-218.

Schot, J., and Geels, F. (2008). Strategic niche management and sustainable innovation journeys: theory, findings, research agenda, and policy. Technology Analysis and Strategic Management, 20, 537-554.

Smith, K., Bandola-Gill, J., Meer N., Stewart, E., and Watermeyer, R. (2020). The Impact Agenda: Controversies, Consequences and Challenges. London: Policy Press.

Soriano, F., and Mulatero, F. (2010). Knowledge policy in the EU: from the Lisbon Strategy to Europe 2020. Journal of the Knowledge Economy, 1, 289-302.

Stanton, T. (2008). New times demand a new scholarship: opportunities and challenges for civic engagement at research universities. Education, Citizenship and Social Justice, 3, 19-42.

Technopolis/Fraunhofer-ISI/UNU-MERIT (2012). Regional Innovation Monitor - thematic paper \#4: the role of universities for regional innovation strategies. Report to European Commission, DG Enterprise and Industry.

Tijssen, R. (2015). Regional performance of universities: knowns and unknowns, opportunities and challenges. Conference: Where Are We With The 'Stairway to Excellence'? The Role of European Universities. Brussels: The Committee of the Regions, 26 June 2015.

Tijssen, R. (2019). Distance matters in a university's local outreach and regional impact, CWTS blog post, 3 June 2019 (www.cwts.nl/blog?article=n-r2x244\&title= distance-matters-in-a-universitys-local-outreach-and-regional-impact).

Tijssen, R., Van de Klippe, W., and Yegros, A. (2019). Distance is not dead: 21st century geography of university-business cooperation, 60-65, EU-SPRI 2019 Conference Book of Abstracts (www.euspri2019.it/wp-content/uploads/Eu-SPRI -2019-Book-of-Abstracts.pdf).

Tijssen, R., Van de Klippe, W., and Yegros, A. (2020). Localization, regionalization and globalization of university-business research cooperation in the United Kingdom. Papers in Regional Science, 99, 1215-1236.

Tijssen, R., and Van Wijk, E. (2020). The European Regional Development Fund and European universities: mapping regional development footprints. Fifth Leiden-Utrecht Workshop on Measuring and Modelling Knowledge Production, Utrecht University, 14 February 2020.

Tödtling, F. and Trippl, M. (2005). One size fits all? Towards a differentiated regional innovation policy approach. Research Policy, 34, 1203-1219.

Trajtenberg, M. (2009). Development policy: an overview. In: Foray, D. (Ed.). The New Economics of Technology Policy. Cheltenham, UK and Northampton, MA, USA: Edward Elgar Publishing, 367-395. 
Uyarra, E. (2010). Conceptualizing the regional roles of universities, implications and contradictions. European Planning Studies, 18, 1227-1246.

Uyarra, E., and Flanagan, K. (2010). From regional systems of innovation to regions as innovation policy spaces. Environment and Planning C-Governance and Policy, 28, 681-695.

Vallance, P., Blažek, J., and Edwards, J. (2018). Smart specialisation in regions with less-developed research and innovation systems: a changing role for universities? Environment and Planning C: Politics and Space, 36, 219-238.

Valero, A., and Van Reenen, J. (2019). The economic impact of universities: evidence from across the globe. Economics of Education Review, 68, 53-67.

Van Steen, J. (2012). Modes of Public Funding of Research and Development: Towards Internationally Comparable Indicators, OECD Science, Technology and Industry Working Papers, 2012/04, OECD Publishing.

Vickers, P., and Bekhradnia, B. (2007). The economic costs and benefits of international students. Higher Education Policy Institute, July 2007 (https://www.hepi.ac .uk/wp-content/uploads/2014/02/32Economiceffectsofinternationalstudents.pdf).

Zukauskaite, E., Trippl, M., and Plechero, M. (2017). Institutional thickness revisited. Economic Geography, 93, 325-345. 